\title{
FUNCTIONAL DELAYED ECHOLALIA: INSIGHTS FROM A MOVIE
}

\author{
Qonitah Nuri Humaira, Emy Sudarwati \\ Brawijaya University (UB), Malang, Indonesia \\ E-mail: qonitahumaira@student.ub.ac.id
}

Received: 2021-10-08

Accepted: 2021-11-21

\begin{abstract}
This study focuses on the analysis of functional delayed echolalia towards an autistic individual in Life, Animated documentary. The obtained data were derived from Owen Suskind's utterances and words in the aforementioned documentary, which the researchers manipulated and structured to fall into two categories of functional delayed echolalia. The study used qualitative descriptive method in analyzing the functional delayed echolalia of Owen Suskind using interactive and non-interactive functional categories of delayed echolalia theory proposed by Vicker (1999). The findings show that there are 8 (eight) out of 9 (nine) types of interactive delayed echolalia were discovered namely Turn taking, Verbal, Completion, Providing information, Labelling, Protest, Request, Calling and Affirmation. Meanwhile, the non- interactive delayed echolalia consists of three types namely non-focused, situation association, and rehearsal. The findings of this study are expected to give a positive impact on both readers who are dealing with children with autism who have echolalia. It will provide information on their language development in order to later determine the ideal method to handle them with care.
\end{abstract}

Keywords: Psycholinguistic Analysis, Autism, Functional Delayed Echolalia

\section{Introduction}

Language acquisition in children is one of the most important milestones in a child's life because the various sorts of linguistic experiences that occur in a child's life will be unforgettable memories that will leave their own mark. With regard to this, children are said to have normal language development when they perform or demonstrate more complex language abilities in conjunction with their age maturity (Manipuspika \& Sudarwati, 2019). In other words, children are said to have typical language development when they perform or demonstrate increasingly complex language abilities in conjunction with their age maturity (Manipuspika \& Sudarwati, 2019).

However, one child's development differs from that of other children for a variety of reasons. Some children have language disabilities, which results in them not developing their language skills. One of the language problems experienced by children is autism. Autism is a spectrum disorder whose symptoms can be presented in various kinds. Autistic children find it difficult to communicate and interact with others, along with expressing their thoughts and feelings. Autism also causes children to have repetition habits, be disappointed with changes in a daily routine, and respond to certain situations in unusual ways (Parents Factsheets, 2010). The habit of repeating words is one of the characteristics attributed to persons' suffering from autism which is known as echolalia. 
Echolalia is defined as the phenomenon of imitative behavior whereby an individual automatic repeat or echo of words that have been used by another speaker (Suzuku et. al., 2012; Grossi et. al., 2013; Shield et. al., 2017). This language abnormalities usually occurs in children who are in the early phase of vocabulary acquisition or among developing children (TD), which is up to age 2.5 years then it gradually disappears (Shield et. al., 2017; Marom et. al., 2018; Soeriawinata, 2018); however it could also happen to individuals who have a variety of disorders to name but a few, intellectual disability, aphasia, dementia, language delay, close head injury, and Gilles de la Tourette syndrome, and Latah reaction (Shield et. al., 2017; Patra \& De Jesus, 2020). Furthermore, when toddlers learn to speak, they usually imitate the sound they hear or Echolalia; thus, Echolalia is a normal part of child development (Brignell et. al., 2018; Williams, 2021). However, echolalic or repetitive speech has often been reported as early descriptions of the syndrome of autistic children and as its primary characteristic (Stefanatos \& Joe, 2008).

People with autism would surely receive an abnormality in responding to the information that they get. However, such a case would be quite different if we compare it to other people in general, as an individual with autism has a brain dysfunction affecting the problem towards the ability to express and cooperate with normal conversation. One of them is the disability of giving a response. Autistic children may have no speech at all (nonverbal) or be highly verbal, or be somewhere in between (Roberts, 2014). On the other hand, people with autistic spectrum disorders are likely to exhibit Echolalia in their speech at some time, which possesses its function and could be an important aspect of language development (Roberts, 2014). Thus, Echolalia may be a part of a child's attempt to have a meaningful exchange with others. Furthermore, in the recent research (DSM-5, APA 2013), Echolalia is no longer called as the communication disability, rather known and considered as one of the "limited and repetitive behavior patterns, interests or activities" along with the "queuing toys or turning objects over."

Moreover, there are numerous studies of Echolalia in people with autism spectrum disorder (ASD), namely case study of communicative disorder of an autistic child (Sumarti, 2017), Echolalia in deaf signing ASD children (Shield et. al., 2017), Echolalia through the musical perspective in ASD children (Marom et al., 2018; Marom et. al., 2020), quantifying repetitive speech in ASD children (van Santen et al., 2013), replacing Echolalia in ASD children (Foxx et. al., 2004), the nature of Echolalia in autism (Grossi et. al., 2013), treatment of Echolalia in autistic individuals (Neely et. al., 2015), and Echolalia as an interactional resource of communication of children with ASD (Sterponi \& Shankey, 2014).

The growing number of experts reiterate the need to understand the echolalia phenomenon more in-depth, such as Echolalia in people with ASD ( Foxx et. al., 2004; van Santen et. al., 2013; Grossi et. al., 2013; Sterponi \& Shankey, 2014; Neely et al., 2015; Sumarti, 2017; Shield et. al., 2017; Marom et. al., 2018; Marom et. al., 2020), Echolalia in society (Christy, 2017; Fitriani et. al., 2019), and Echolalia from a medical perspective (Suzuku et. al., 2012; Suzuku et. al., 2009; Abusrair \& AlSaeed, 2020; Paucar et. al., 2021). However, there is research on Echolalia in movies, such as a study done by Mufidah \& Antono (2019). The illustration of social real-life motion and action created from the chain of photographic or recorded images is called a movie; thus, a movie or film can portray or represent life (Fadilah, 2021). Therefore, studying Echolalia in film can catch the essence of the actual echolalia phenomenon in life.

Despite huge concerns on the investigation on echolalia, it seems that an investigation on language development related to DS case depicted in movie is still under researched. 
Therefore, the present study tries to fill in the gap by doing another research on echolalia depicted in film by giving more emphasis on types of echolalia and the cause of such type occurence. The main focus of this study, which is based on the documentary film Life, Animated, is the language deficit experienced by autistic children, also known as delayed Echolalia. Owen, the autistic child shown in the documentary video, has been quiet since he was diagnosed with autism at the age of three. But one day, Owen repeated a single word that was thought to be gibberish. He kept repeating the gibberish words, and it was later discovered that the words labeled gibberish were exact lines from Disney Animated Movies. Therefore, such activity that Owen did is Echolalia. Only by repeating such exact lines could Owen improve his language skills and communication abilities. One of the reasons the researchers chose this specific documenter was because it presented the same story about how an autistic person improved his language and capacity to speak and engage with others. There is a wealth of knowledge to be learned by examining such methods of communication behavior as perceived by an autistic individual and getting an insight from a film can be one of the alternatives.

The new study tries to discover the type of Echolalia practiced by character Owen Suskind in the Life, Animated documentary, as well as the possible causes of possessing that sort of Echolalia. This study is expected to provide a more complete explanation and brief information on how a young adult with autism could communicate by describing the methods employed by the autistic young adult himself whether the method itself would be interactive or non-interactive delayed Echolalia. Learning and discussing some varieties of delayed echolalia in greater depth may be beneficial in learning how to behave or comprehend while communicating with autistic individuals. In addition, such understanding would provide any information on how Echolalia can aid in the linguistic development of autistic children.

\section{Literature Review}

Echolalia is typically defined as the socially awkward or inappropriate verbatim repetition of part or all of a previously spoken utterance (Valentino et. al. 2012) (Valentinoo, 2012). It is the most prevalent echo phenomena and is a pervasive non-voluntary, automated, and automatic activity (Patra \& De Jesus, 2020). Echolalia is classified into two forms based on its timing: instant and delayed. Immediate echolalia refers to utterances that are repeated immediately or after a little delay, whereas delayed echolalia refers to utterances that are repeated after a large delay, making it more difficult for others to understand (Prizant \& Rydell, 1984). There are two varieties of delayed echolalia: interactive delayed echolalia and non-interactive delayed echolalia (Vicker,1999). An effort or attempt to communicate and interact with other individuals, such as turn-taking, is referred to as interactive or functional delayed echolalia. Non-interactive echolalia is primarily utilized for personal reasons and serves no communicative purpose.

\subsection{Causes of Echolalia}

Echolalia occurs in all children who learn a spoken language. Most children develop independent thought as they grow older, or about the age of 18 months, while others regurgitate what they hear. Children that have trouble talking continue to echo expressions for far longer periods of time. Echolalia is particularly common among autistic youngsters. Approximately $75 \%$ of talkative autistic children go through periods of noticeable echolalia (Marom, 2018). Adults can develop echolalia as a result of acute amnesia or brain trauma 
while seeking to regain their speech abilities. Some people only experience this problem when they are irritated or anxious. Others are frequently exposed to it, which may cause them to become mute owing to their incapacity to speak.

\subsection{Functional Categories of Delayed Echolalia}

Delayed echolalia defines as the verbal repetition of utterances that were previously heard and then repeated after some delay of a few minutes, hours, days, weeks, months, or years (Vicker, 1999). Below is the table of interactive and non-interactive functional categories of delayed echolalia proposed by Viktor (1999).

\begin{tabular}{|l|l|}
\hline \multicolumn{1}{|c|}{ Category } & \multicolumn{1}{c|}{ Description } \\
\hline Turn taking & utterances used as turn fillers in a conversation \\
\hline Verbal completion & $\begin{array}{l}\text { utterances used to complete familiar conversation initiated } \\
\text { by others }\end{array}$ \\
\hline Providing information & $\begin{array}{l}\text { utterances to offer new information, which not apparent } \\
\text { from situational context }\end{array}$ \\
\hline Labeling & utterances labeling objects or actions \\
\hline Protest & $\begin{array}{l}\text { utterances protesting actions of others. May be used as } \\
\text { prohobitations of other's action }\end{array}$ \\
\hline Request & utterances used to request things \\
\hline Calling & $\begin{array}{l}\text { utterances used to call attention to self or to initiate/ } \\
\text { maintain interaction }\end{array}$ \\
\hline Affirmation & $\begin{array}{l}\text { utterances used to indicate affirmation of previous } \\
\text { utterance }\end{array}$ \\
\hline Directive & utterances used to direct another's actions \\
\hline
\end{tabular}

Table 1. Functional Categories of Delayed Echolalia (Interactive)

\begin{tabular}{|l|l|}
\hline \multicolumn{1}{|c|}{ Category } & \multicolumn{1}{c|}{ Description } \\
\hline Nonfocused & $\begin{array}{l}\text { utterances with no apparent communicative intent or } \\
\text { relevance to the situational context }\end{array}$ \\
\hline Situation association & $\begin{array}{l}\text { utterances with no apparent communicative intent which } \\
\text { triggered by an object, person, or situation }\end{array}$ \\
\hline Self-directive & $\begin{array}{l}\text { utterances which serve to regulate one's own actions. } \\
\text { Usually produced along with motor activity }\end{array}$ \\
\hline Rehearsal & $\begin{array}{l}\text { utterances produced with low volume followed by louder } \\
\text { interactive production }\end{array}$ \\
\hline Label & $\begin{array}{l}\text { utterances labeling objects or actions with no apparent } \\
\text { communicative intent }\end{array}$ \\
\hline
\end{tabular}

Table 2. Functional Categories of Delayed Echolalia (Non Interactive)

\subsection{Echolalia in Autism Context}

Autism spectrum disorder (ASD) is a cognitively specified neurodevelopmental disorder coupled with minimal and repeated activities and the existence of social language impairment. (American Psychiatric Association [APA], 2013). People with autism would have trouble practicing and conceiving language, including the repeating of some sentences or specific words, as well as communication limitations. Aside from the technique by which 
they communicate, people with autism face challenges in engaging in interactions with others.

Autism is characterized by linguistic conduct that results in faulty receptive and expressive skills. utterances, Skinner (1957) noted that verbal behavior is classified into four varieties (verbal optant), which are demanding, tacking, intraverbal, and echoic. The first is demand, which is one of the language functions used when someone requests or wants something. The second is tact, which is one of the linguistic functions used when a person wished to describe something that could be seen, heard, smelt, and felt by the human senses. For example, when we observe youngsters who have been introduced to something new, their parents usually tell them what it is called. Like the word ball, anytime toddlers encounter something with a "rounded shape," they naturally refer to it as a ball. Knowing that they already represent the word "ball" as a label for a rounded form item. Unfortunately, children with autism do not have such abilities in general.

The third sort of verbal behavior is intraverbal, which is controlled by the other verbal operant. And, in general, children with autism have a similar pattern that implies a weakness for demand and intraverbal, and an advantage for touch or echo as they get more vocal. The final sort of verbal behavior is echoic, which causes the speaker to imitate specific sounds or words that have been pronounced by others. Echolalia is the term used to describe vocal echoing behaviors. For many autistic children, echolalia is an important first step toward more typical types of verbal communication.

\section{Research Method}

\subsection{Causes of Echolalia Types of Study}

This study employs the qualitative-descriptive method, with the results of the study itself being explained descriptively. The discovered and gathered data would be served and displayed in the form of a table and numbers, whilst the analyzed data, which includes both interactive and non-interactive delayed echolalia data, would be described descriptively. The qualitative method necessitates that data be articulated rather than counted (Katz, 2015). Referring back to the previous statement, the studied data that would be explained and the discovered data that would be acquired based on utterances, statements, and behaviors would be applied and continued through the qualitative technique.

\subsection{Data and Data Source}

The documentary film Life, Animated, which was released in 2016, is the source of the statistics. All of the data collected and gathered are utterances and expressions spoken by Owen Suskind, who has autism, in the documentary film Life, Animated. All of the phrases expressed and spoken by the autistic boy himself in the aforementioned documentary film were used as context.

\subsection{Instruments, and Data Collection Technique}

The primary instrument in this study is the researchers themselves, who are assisted with a data sheet. The researchers proceeded through several stages of data collection, and those were watching the stated documenter movie as the main source of this research, understanding deeper through the script of the movie itself, arranging the data sheets to fill, rechecking on what had been observed and read, re-watching the movie itself, analyzing all of the scenes while comparing and analyzing the script itself as the main purpose of such research. 


\subsection{Data Analysis}

The acquired data was then categorised based on the precise categories employed and whether it was interactive or non-interactive. Researchers studied only the data that were focused on the data arrangement depending on the type of delayed echolalia while examining the inserted data in the data sheets. Furthermore, the researchers sorted the selected data and grouped the data based on the two data sheets, which are types of interactive delayed echolalia and types of non-interactive delayed echolalia. For the kinds and additional explanation, researchers provided collected and selected data from the screenplay of the documentary film itself.

\section{Results and Discussion}

\subsection{The Analysis of Functional Delayed Echolalia Performed by the main character in Life, documentary movie}

The findings that have already been studied and observed by the researchers would be shown through the following table. Furthermore, the researchers would describe the finding in detail to get a closer look on the case of echolalia performed by the movie character.

\begin{tabular}{|c|c|c|c|}
\hline No. & Data & Data Number & Category \\
\hline 1. & $\begin{array}{l}\text { Case worker: Most people at your age, they } \\
\text { don't meet the love of their life forever... } \\
\text { Owen: What? } \\
\text { Case Worker: At your age. } \\
\text { Owen: "Boy loves girl, boy loses girl, boy love... } \\
\quad \text { Gets girl back in the end." }\end{array}$ & 1 & Turn taking \\
\hline 2. & $\begin{array}{l}\text { (Owen's whine) } \\
\text { Dad: alright come on } \\
\text { Owen: Don't whine? } \\
\text { Dad: Don't whine. } \\
\text { Owen: A little kid whines. } \\
\text { Dad: A little kid whines. }\end{array}$ & 2 & $\begin{array}{c}\text { Verbal } \\
\text { Completion }\end{array}$ \\
\hline 3. & $\begin{array}{l}\text { (Jonathan Freeman walks into the classroom) } \\
\text { Owen: Jonathan Freeman is a great actor who } \\
\text { also does voices for animated Disney films. }\end{array}$ & 3 & $\begin{array}{l}\text { Providing } \\
\text { information }\end{array}$ \\
\hline 4. & $\begin{array}{l}\text { (dad pretend to be Lago "the parrot' in Aladdin } \\
\text { with Owen's puppet) } \\
\text { Dad: I hear him say... } \\
\text { Owen: I love the way } \\
\text { your foul little mind works." } \\
\text { (the next line of dialogue of Jafar, the villain, to } \\
\text { his evil sidekick, Lago) }\end{array}$ & 4 & Labelling \\
\hline 5. & $\begin{array}{l}\text { Marie: Bonjour, Owen. } \\
\text { I am very pleased } \\
\text { to meet you, Owen. } \\
\text { Owen: Thanks, Marie. }\end{array}$ & 5 & Protest \\
\hline
\end{tabular}




\begin{tabular}{|c|c|c|c|}
\hline & $\begin{array}{l}\text { (Owen walks away from Marie) } \\
\text { Marie: Are you fine? } \\
\text { Owen: Yeah. } \\
\text { (walk further away again) } \\
\text { Mom: Owen, come. Come chat, say hi. } \\
\text { Owen: Yes, I am. } \\
\text { Dad: He doesn't like smoking. } \\
\text { Owen: I don't like the smoking. } \\
\text { Dad: A lot of people smoke in France }\end{array}$ & & \\
\hline 6. & $\begin{array}{l}\text { Owen: Is this the right mailbox? } \\
\quad \text { Excuse me. } \\
\quad \text { Is this the right mailbox? } \\
\text { Neighbor: Okay, can I see which one you have? } \\
\text { Owen: Which one's mine? } \\
\text { W: Yeah. }\end{array}$ & 6 & Request \\
\hline 7. & $\begin{array}{l}\text { Owen: Morning Emily } \\
\text { Owen: Morning Emily! } \\
\text { (Emily keep on walking and not immediately } \\
\text { respond him) } \\
\text { Owen: Morning Emily! } \\
\text { Emily: Good Morning Owen. }\end{array}$ & 7 & Calling \\
\hline 8. & $\begin{array}{l}\text { Walter: Pretty excited of what's gonna happen } \\
\text { for you, bud. } \\
\text { Owen: Yeah. } \\
\text { Walter: You got a lot more chapters to write. } \\
\text { Owen: A lot more chapters to write. }\end{array}$ & 8 & Affirmation \\
\hline 9. & - & 9 & Directive \\
\hline
\end{tabular}

Table 3. Interactive-Delayed echolalia found in Life, Animated documentary

\begin{tabular}{|c|c|c|c|}
\hline No. & \multicolumn{1}{|c|}{ Data } & $\begin{array}{c}\text { Data } \\
\text { Number }\end{array}$ & Category \\
\hline 1. & $\begin{array}{l}\text { (after moving in a new apartment on his own, } \\
\text { Owen walks in circles in the front yard of his } \\
\text { apartment) } \\
\text { [Owen unclearly utters the dialogue of one of } \\
\text { the Disney films] }\end{array}$ & $\begin{array}{c}\text { Non- } \\
\text { focused }\end{array}$ & 10 \\
\hline 2. & $\begin{array}{l}\text { Owen getting ready for his graduates] } \\
\text { Owell, it's like I always say, Your Majesty. } \\
\text { Children got to be free to lead their } \\
\text { own life [Repeating Sebastian dialogue } \\
\text { in the little mermaid movie }\end{array}$ & $\begin{array}{c}\text { Situation } \\
\text { association }\end{array}$ & \\
\hline
\end{tabular}




\begin{tabular}{|c|c|c|c|}
\hline 3. & $\begin{array}{c}\text { Owen: hi Emily? (softly says to himself) } \\
\text { Owen: hi Emily! (shouting) } \\
\text { [Emily doesn't respond] } \\
\text { Owen: good luck Emily (shouting) } \\
\text { [Emily still not responding] }\end{array}$ & 12 & Rehearsal \\
\hline 4. & - & 13 & $\begin{array}{c}\text { Self- } \\
\text { directive }\end{array}$ \\
\hline 5. & - & 14 & Labelling \\
\hline
\end{tabular}

Table 4. Non-interactive Delayed echolalia found in Life, Animated documentary

Both of the tables above indicate the quantity of data discovered from Owen Suskind, the subject of the documentary Life, Animated. The first table shows that in this investigation, eight out of nine types of interactive delayed echolalia were discovered. In addition, the second table shows that there are three types out of five types of noninteractive delayed echolalia. For the further details of the interactive, there are eight types namely (1) Turn taking, (2) Verbal, Completion, (3) Providing information, (4) Labelling, (5) Protest, (6) Request, (7) Calling and (8) Affirmation. Meanwhile, the non- interactive delayed echolalia consists of three types namely (1) Non-focused, (2) situation association, and (3) rehearsal. The elaboration of both interactive delayed echolalia and non- interactive delayed echolalia is presented in the following section.

\subsubsection{Interactive Delayed Echolalia}

\section{a. Turn taking \\ Datum 1}

Case worker: Most people at your age, they don't meet the love of their life forever...

Owen: What?

Case Worker: At your age.

Owen: "Boy loves girl, boy loses girl, boy love...

Gets girl back in the end."

Based on what Owen said, Owen was still on topic, albeit by the time he said it, he was roaming around back and forth and appeared to be out of focus because he had just broken up with his girlfriend. Although Owen's response does not appear to be correct, it is the repeating of romantic quotations that most people, including Owen, are familiar with. Furthermore, the quotes that he already said were still in the same topic with what was spoken by the caseworker. Such quotes that he said was the form of content shifting in a verbal exchange proceeded Alternatively and it was a sign of a turn taking types from interactive delayed echolalia (Vicker, 2009).

\section{b. Verbal Completion \\ Datum 2}

(Owen's whine)

Dad: alright come on

Owen: Don't whine?

Dad: Don't whine. 
Owen: A little kid whines.

Dad: A little kid whines.

Owen would deliver a speech about an autistic person at a conference in France. His father asked him to construct his own speech so that whatever he said was based on his words. Owen was whining and pounding his head because he wasn't sure what to write, and his father reacted angrily by the time Owen finished. Following that, Owen said an instruction that his father frequently said whenever Owen was whining. Therefore, such repetition was established for his father's reaction when he was whining. Repeating some words that are commonly used in daily life in a similar context is an indication of interactive delayed echolalia verbal completion. After hearing "a little kid whines," he suddenly understood he was no longer a youngster and stopped crying.

\section{c. Providing information \\ Datum 3}

(Jonathan Freeman walks into the classroom)

Owen: Jonathan Freeman is a great actor who also does voices for animated Disney films.

As he entered the room, Owen initiated a conversation by mentioning Jonathan. Owen repeated his words on Jonathan's statement because he loved Disney and was familiar with such a fact. He shared some information with his pals by saying some facts about Jonathan, which began with Jonathan inquiring how Owen was feeling, to which he replied, "fine," and was abruptly followed by sharing some information about Jonathan. Such activity that Owen did as he gave information to all of those people as a form of respond about the coming of Jonathan Freeman it showed the type of providing information from interactive delayed echolalia.

\section{d. Labelling \\ Datum 4}

(dad pretend to be Lago "the parrot' in Aladdin with Owen's puppet)

Dad: I hear him say...

"I love the way

your foul little mind works."

That's the next line of conversation. That's the villain, Jafar, speaking to his wicked sidekick, Lago. Owen looked melancholy one night after his brother's birthday as he sat on his bed in his room reading his book, and there was a puppet Lago, one of the characters from the animated Disney film Aladdin. As soon as his father took the doll, he began imitating the sounds of the characters. While concealing, Owen did not mention or state the character's name, instead repeating the speech from the film, which was uttered by Jafar to Lago, another character in the film. By repeating such conversations to label a single object, such behavior is what is called as labelling.

\section{e. Protest \\ Datum 5}

Marie: Bonjour, Owen. 


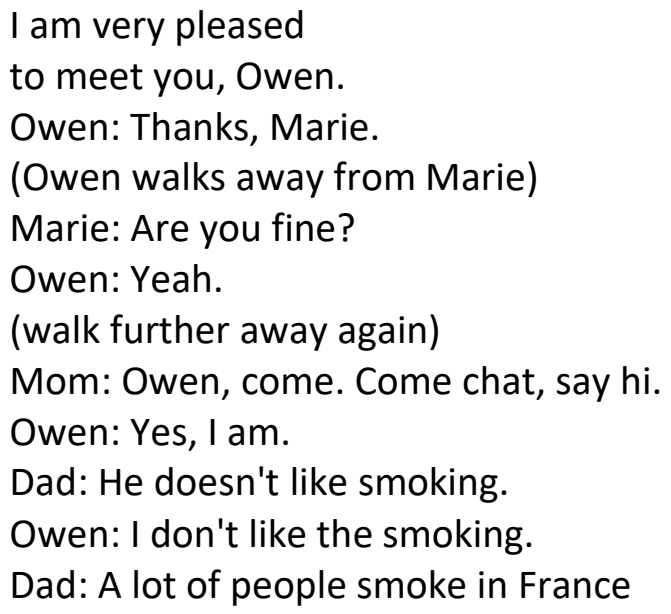

When Owen arrived in France, he was greeted by Marie, a member of the team in charge of the conference. Owen returned Marie's greeting as he continued to go forward while evading the second time he was asked. Owen finally came over to them when his mother called him, and his father recognized what was causing him to keep fleeing was Marie's smoking. Owen had repeated his father's statements by the time his father told Marie that he did not enjoy smoke. Owen's dodging gesture was a type of protest, however in the end he could speak up a little louder about what he was protesting. He made such movements as a kind of protest without saying anything other than what he repeated based on what his interlocutor stated collocutor said.

\section{f. Request \\ Datum 6}

\section{Owen: Is this the right mailbox?}

Excuse me.

Is this the right mailbox?

Neighbor: Okay, can I see which one you have?

Owen: Which one's mine?

W: Yeah.

Owen was already living on his own in his own apartment, and when it came time to retrieve his mail from his mailbox, he had some difficulty opening it. When he later spotted his neighbor, he abruptly shouted and exclaimed, "Is this the right mailbox?" as he repeated the same sentences louder knowing that his neighbor had not yet responded as a sort of help request, despite the fact that he had not greeted him or said anything else. However, his neighbor completely understood that he asked for assistance, as such conduct is a request in the context of Owen's words.

\section{g. Calling}

\section{Datum 7}

Owen: Morning Emily

Owen: Morning Emily!

(Emily keep on walking and not immediately respond him)

Owen: Morning Emily!

Emily: Good Morning Owen. 
Emily was Owen's ex-girlfriend, and when he returned home from cycling and spotted her stepping out of her apartment, he was overjoyed because he hadn't seen her in a long time. Emily was observed having a conversation with another girl. Owen greeted Emily repeatedly because Emily did not answer the first time, and such repeating utterances were made by Owen to get Emily's attention. That was one of the calling varieties of interactive delayed echolalia.

\section{h. Affirmation \\ Datum 8}

Walter: Pretty excited of what's gonna happen for you, bud.

Owen: Yeah.

Walter: You got a lot more chapters to write.

Owen: A lot more chapters to write.

Owen was walking with his brother, Walter, who was discussing some of the barriers and challenges that Owen would encounter after graduating from high school. During a conversation, Owen echoed what Walter stated, stating that there is "a lot more chapter to write." By repeating such a phrase, Owen indicated that he agreed with what Walter said. He stated, without adding additional words, that he agreed with what his interlocutors said by repeating the expressed words.

\subsubsection{Non-Interactive Delayed Echolalia}

\section{a. Non-focused}

\section{Datum 10}

(after moving in a new apartment on his own, Owen walks in circles in the front yard of his apartment)

[Owen unclearly utters the dialogue of one of the Disney films]

Owen was frightened and terrified since he was about to live alone, away from his family. Furthermore, after he finished moving his belongings in the flat, he went outside and strolled about in the front yard, unclearly reciting a certain Disney line. He continued doing so until he felt better and returned to his residence. Non-focused scenario could be happening towards people with echolalia as they are feeling worried, terrified or in a pain. In addition, in this scenario, Owen kept repeating the Disney line since it was one of the most familiar things he understood at the moment he needed to comply with the foreign surroundings and adapt to it. He continued to engage in such behavior anytime he felt anxious.

\section{b. Situation association \\ Datum 11}

[Owen getting ready for his graduates]

Owen: Well, it's like I always say, Your Majesty. Children got to be free to lead their own life [Repeating Sebastian dialogue in the little mermaid movie]

Owen is getting ready for his graduation, and as he was getting ready in front of the mirror, he repeated one of the phrases from the Little Mermaid movie's character, Sebastian. The dialogue itself was about the character Sebastian's advice to Monarch Triton, 
as he advised the king himself about how princess Ariel is already grown up and free to pick her own life path. And, because Owen was in a similar circumstance, he related to himself by repeating such talks. In this case, it may be said that an autistic person had some kind of mental preparation for the scenario he is in. And as he went through it, he would recall any precise moment that was shown to him.

\section{c. Rehearsal \\ Datum 12}

Owen: hi Emily? (softly says to himself)

Owen: hi Emily! (shouting)

[Emily doesn't respond]

Owen: good luck Emily (shouting)

[Emily still not responding]

Owen was strolling alone when he noticed Emily from a distance wanting to get into the van. Before shouting with such a stronger voice, he whispered it quietly to himself first, then louder to make Emily hear. According to Vicker (1999), practice is indicated by a lowervolume utterance accompanied by a louder speech. Therefore, this implies that the exercises the non-interactive delayed echolalia type rehearsal behavior. This is considered as rehearsal type as Owen merely stated the word unclearly by whispering for a practice making sure that he meant to say that. Once he was sure that that particular word is that what he meant then he managed to say that several times.

\subsection{Discussion}

After the data analysis was carried out, the researchers found that the echolalia language disorders found in children are divided into two types interactive and noninteractive echolalia type. They are (1) Turn taking, (2) Verbal, Completion, (3) Providing information, (4) Labelling, (5) Protest, (6) Request, (7) Calling and (8) Affirmation. Meanwhile, there are three types out of five types of non-interactive delayed echolalia namely (1) Non-focused, (2) situation association, and (3) rehearsal. Those types of echolalia occurred for different purpose of occurrences depending on the context of the situation explaining its situation. The subject come to that kind of echolalia type as he managed to bring certain causalities. The interactive echolalia is done when Owen is in relation to the event in interactive way when he has interlocutor to interact with while the non interactive ones occur due to Owen's initiative in having the practice by saying words to whom anybody else would not like to react as they are stated in whisper like what happened in rehearsal type and like the one when he practiced for a situation speech event.

The findings of a current study differ from those of a prior study conducted by Mufidah and Antono (2019), which similarly examined linguistic dysfunction in a movie character. Their analysis only discovered one instance of instantaneous echolalia performed by the character in the film; however, no instance of delayed echolalia was discovered. This could be because Mufidah and Antono (2019) focused on general language dysfunction rather than echolalia, such as the use of metaphors, reversal of personal pronouns, and difficulty with deictic words. A recent study, on the other hand, concentrated on Owen's echolalia phenomena in detail, particularly delayed echolalia, in the reported footage. The genre of the film may also have an impact on the outcome. Mufidah and Antono's (2019) film is an Indonesian omnibus film with love nuances, and they choose the short film Malaikat Juga 
Tahu. The film utilized in a recent study, on the other hand, is well-documented. A documentary film gives more reflections on human beings's daily life so the occurrences of life events in this case life events represented by the echolalia suffered is much more detail and vary in kinds. However, there is a similarity between the findings of the present investigation and the prior study conducted by Marom et. al (2018). Both recent and previous studies discovered evidence of delayed echolalia. Marom et. al. (2018) identified 33 of 40 segments as having delayed echolalia. Because a movie represents life, this could lead to the conclusion that the echolalia phenomenon in cinema and real life is the same.

Following that, the current discovery demonstrates that children with autism can exhibit a variety of echolalia kinds. This film clearly demonstrates one of Owen's parents' options, which is to perform an efficient language planning program supervised by a health therapist, which can also be implemented to children in real life who are suffering from the same condition. By incorporating children with autism in this type of therapy, measurable language goals may be examined at each milestone of the children's language development. When each milestone's aim is met, the target is raised. On the other hand, if a plan fails, evaluation and a new approach must be re-evaluated for a better outcome. The findings of the present study may only be applicable to children suffering from autism as depicted in the movie as other children suffering from other syndrome may perform another type of echolalia. Further researchers are suggested to conduct a study on children suffering from echolalia in more movies as there might be differences in types of echolalia which is needed to open up our horizon on echolalia types and how to handle this.

\section{Conclusion}

Language use and growth, both oral and written, are inextricably linked to human life, particularly in youngsters. This study investigates the category of functional delayed echolalia used by Owen Suskind in the documentary Life, Animated. There are correct types of interactive delayed echolalia out of nine varieties based on the data that was discovered, collected, and analyzed. They are Turn taking, Verbal, Completion, providing information, Labelling, Protest, Request, Calling, and Affirmation. And in this particular type, the frequently found one is the affirmation type. Owen generally utilized this style when he thought another person's statement was correct or agreed with him. In such a circumstance, he did not say generic phrases like "yeah, I agree," but rather echoed the other's stated statement as a sort of agreement with the declaration made by his interlocutors.

Then, out of the five categories of non-interactive delayed echolalia, there are three: non-focused, scenario association, and rehearsal. This particular variety is also one of the most common. Therefore, for such a topic, it was revealed that when an autistic person felt furious or anxious, the recall was highly proceeded with no intention of being referred to others. Owen usually produced non-focused non-interactive delayed echolalia when he was nervous, angry, or unhappy.

The researchers hope that further researchers who are interested in conducting research on the psycholinguistic topic, particularly on the method of how people with special needs communicate, will use this study as a reference or will apply any other different perspectives for analyzing the method of how children with autism communicate, particularly in the context of delayed echolalia. Furthermore, by utilizing additional objects and instruments, the specialized research on the topic of delayed echolalia could be widened. This unique research still had certain flaws, but the researchers expect that this study will provide additional knowledge for other people learning how specific people with 
requirements communicate and how we are supposed to respond, behave, and maybe aid them.

The findings of this study may be able to empirically help providing evidence or information dealing with echolalia in a child with autism disorder. More studies need to be conducted by involving more research participants to get thorough and more extensive review on language performances performed by persons with Autism syndrome. In addition, the result of this study may also give a positive impact on whoever who happen to have similar cases of how to deal with children suffering from echolalia as a result of its autism disorder and provide information about their language development in order to subsequently identify the best option to handle them with care

\section{References}

Abusrair, A. H., \& AlSaeed, F. (2020). Echolalia Following Acute Ischemic Stroke. The Neurohospitalist, 11(1), 91-92.

Autism Spectrum Disorder. (2017). In Diagnostic and statistical manual of mental disorders: DSM-5 (5th ed.). Arlington, VA, USA: American Psychiatric Association.

Brignell, A., Morgan, A. T., Woolfenden, S., Klopper, F., May, T., Sarkozy, V., \& Williams, K. (2018). A systematic review and meta-analysis of the prognosis of language outcomes for individuals with autism spectrum disorder. Autism \& Developmental Language Impairments, 3, 2396941518767610.

Christy, N. A. (2017). The Interjection Of The Maanyan Language Of The One Of People Who Has Latah In Hayaping Village, Awang Subdistrict, Barito Timur Regency. Jurnal Bahasa Sastra dan Pembelajarannya, 5(1), 133. 10.20527/jbsp.v5i1.3718

Fadilah, I. (2021). Speech Features of Women Characters in Love, Rosie Movie (Doctoral dissertation, UIN Sunan Gunung Djati Bandung).

Fitriani, N. H., Kurniawati, F., \& Sumarlam, S. (2019). Ekspresi Verbal Siswa Latah di Sma Negeri 1 Sukoharjo. Diglossia: Jurnal Kajian Ilmiah Kebahasaan dan Kesusastraan, 10(2), 87-95.

Foxx, R.M., Schreck, K.A., Garito, J. et. al. (2004). Replacing the Echolalia of Children With Autism With Functional Use of Verbal Labeling. Journal of Developmental Physical Disabilities 16 (4), 307-320. https://doi.org/10.1007/s10882-004-0688-5

Grossi, D., Marcone, R., Cinquegrana, T., \& Gallucci, M. (2013). On the differential nature of induced and incidental echolalia in autism. Journal of Intellectual Disability Research, 57(10), 903-912.

Katz, J. (2015). A theory of qualitative methodology: The social system of analytic fieldwork. Méthod (e) s: African Review of Social Sciences Methodology, 1(1-2), 131146.

Sterponi, L. \& Shankey, J. (2014). Rethinking echolalia: repetition as interactional resource in the communication of a child with autism . Journal of Child Language, 41, pp 275-304 doi:10.1017/S0305000912000682

Manipuspika, Y. S., \& Sudarwati, E. (2019). Phonological Development of Children With Speech Delay. RETORIKA: Jurnal IImu Bahasa, 5(1), 12-22.

Marom, M. K., Gilboa, A., \& Bodner, E. (2018). Musical features and interactional functions of echolalia in children with autism within the music therapy dyad. Nordic Journal of Music Therapy, 27(3), 175-196.

Marom, M., Gilboa, A., \& Bodner, E. (2020). Countertransference responses of one music therapist to autistic echolalia. Nordic Journal of Music Therapy, 29(3), 222-239. 
Mufidah, N. I., \& Antono, M. N. (2019). Gangguan Berbahasa Tokoh Abang Dalam Film Rectoverso "Malaikat Juga Tahu"(Kajian Psikolinguistik). Jurnal Pendidikan Bahasa dan Sastra Indonesia Metalingua, 4(2), 71-76.

Neely, L., Gerow, S., Rispoli, M., Lang, R., \& Pullen, N. (2015). Treatment of Echolalia in Individuals with Autism Spectrum Disorder: A Systematic Review. Review Journal of Autism and Developmental Disorders, 3(1), 82-91. doi:10.1007/s40489-015-0067-4

Parents Factsheets. (2010, April). Retrieved from educateiowa: http://www.educateiowa.gov/sites/files/ed/documents/Parent-

Factsheets_April2010_Autism.pdf

Patra KP, De Jesus O. Echolalia. [Updated 2021 Feb 7]. In: StatPearls [Internet]. Treasure Island (FL): StatPearls Publishing; 2021 Jan-. Available from: https://www.ncbi.nlm.nih.gov/books/NBK565908

Paucar, M., Almqvist, H., Björkhem, I., \& Svenningsson, P. (2021). Hyperkinesias and Echolalia in Primary Familial Brain Calcification. Annals of Neurology, 89(2), 418.

Roberts, J. M. (2014). Echolalia and Language development in children with autism. In Communication in Autism (pp. 56-58). Amsterdam, The Netherlands: John Benjamins Publishing Company

Shield, A., Cooley, F., \& Meier, R. P. (2017). Sign language echolalia in deaf children with autism spectrum disorder. Journal of Speech, Language, and Hearing Research, 60(6), 1622-1634.

Skinner, B. F. (1957). Verbal behavior. Cambridge: Prentice Hall. https://doi.org/10.1037/11256-000

Soeriawinata, R. (2018, September 11). Penanganan Echolalia Pada Anak Autis Usia Dini. Retrieved December 28, 2020, from https://www.rurysoeriawinata.com/memahamiecholalia/

Stefanatos, G. A., \& Joe, W. Q. (2008). Autistic disorder. In J. E. Morgan \& J. H. Ricker (Eds.), Textbook of clinical neuropsychology (pp. 185-260). London, GB: Taylor \& Francis.

Sterponi, L., \& Shankey, J. (2014). Rethinking echolalia: Repetition as interactional resource in the communication of a child with autism. Journal of child language, 41(2), 275304.

Sumarti, E. (2017). Gangguan Komunikatif dalam Tuturan Lisan Anak Autis. LITERA, 16(2).

Suzuku, T., Itoh, S., Arai, N., Kouno, M., Noguchi, M., Takatsu, M., \& Takeda, K. (2012). Ambient echolalia in a patient with germinoma around the bilateral ventriculus lateralis: A case report. Neurocase, 18(4), 330-335.

Suzuku, T., Itoh, S., Hayashi, M., Kouno, M., \& Takeda, K. (2009). Hyperlexia and ambient echolalia in a case of cerebral infarction of the left anterior cingulate cortex and corpus callosum. Neurocase, 15(5), 384-389.

Valentino, A. L., Schillingsburg, M. A., Conine, D. E., \& Powell, N. M. (2012). Decreasing echolalia of the instruction Bsay^ during echoic training through use of the cuespause-point procedure. Journal of Behavioral Education, 21, 315-328. doi: 10.1007/s10864-012- 9155-z.

van Santen, J. P., Sproat, R. W., \& Hill, A. P. (2013). Quantifying repetitive speech in autism spectrum disorders and language impairment. Autism research : official journal of the International Society for Autism Research, 6(5), 372-383. https://doi.org/10.1002/aur.1301

Vicker, B. (1999). Functional categories of delayed echolalia. The Reporter, 4(2), 7-10. 
Vicker, B. (2009). Functional categories of immediate echolalia. Bloomington, IN: Indiana Resource Center Autism.

Williams J.H.G. (2021) Echolalia. In: Shackelford T.K., Weekes-Shackelford V.A. (eds) Encyclopedia of Evolutionary Psychological Science. Springer, Cham. https://doi.org/10.1007/978-3-319-19650-3_3338

Williams, R. R. (2016). Life, Animated. Retrieved October/November, 2020, from https://www.scripts.com/script/life,_animated_12571 